\title{
病院楽剤部における睓算化の現状
}

\author{
米澤和明，園田正信，中尾泰史，青山敏信，堀岡正義 \\ 九州大学医学部附属病院薬剈部*
}

\section{The Present Condition of Computerized Systems in Hospital Pharmacies}

\author{
KAZUAKI YONEZAWA, MASANOBU SONODA, YASUSHI NAKAO, \\ TOSHINOBU AOYAMA, and MASAYOSHI HORIOKA \\ Hospital Pharmacy, Faculty of Medicine, Kyushu University*
}

(Received March 28, 1983)

\begin{abstract}
We investigated the current situation of computerization of hospital pharmacies at 40 national university hospitals (national), 2 private university hospitals and 12 general hospitals (others), all utilizing computers at present.

The computerized system is now used in many hospitals for efficient administrative and accounting functions. For example, $59.0 \%$ of the nationals and $92.3 \%$ of the others use the system for registration of patients, and $56.4 \%$ of the nationals and $92.3 \%$ of the others for accounting. Moreover, computers are rapidly introduced into other sections $: 43.6 \%$ of the nationals and $53.8 \%$ of the others use them for laboratory systems, $41.0 \%$ and $84.6 \%$ for pharmacy systems, $12.8 \%$ and $23.1 \%$ for $\mathrm{X}$-ray systems.

$45.7 \%$ of the nationals and $84.6 \%$ of the others use computer in control of drugs, $22.5 \%$ and $38.5 \%$ in dispensing service, and $12.5 \%$ and $30.8 \%$ in drug information services.

The hospital pharmacy practices are closely related to the works of the other hospital sections. Therefore, they are very important for the progress of hospital function when designing systems and for the development of medical treatment.
\end{abstract}

Keywords— hospital pharmacy; computerized system; national university hospital; private university hospital; general hospital; administration; accounting; registration; dispensing; drug information; therapeutic drug monitoring support system; medical treatment.

\section{は じめに}

近年, 薬物療法の発展にともない病院薬剂部業務は多 様化し, 従来からの調剂, 製剂, 薬品管理, 薬品試験, 菓品情報などに加えて薬物血中濃度測定などの新しい業 務も行われてきており, その内容も高度に専門化し, そ れにつれて薬剤部で処理する情報量の著しい増加をみて いる.

多くの病院では情報の処理・伝達の質的向上と合理化 を目的として電算機の有効利用に努めている. その利用 形態は病院の性格, 規模および処理対象とする業務の種

* 福岡市東区馬出 3丁目1-1；1-1，Maidashi 3chome, Higashi-ku, Fukuoka, 812 Japan
類により異なるが，薬剤部においても多様化する業務を 効率よく処理し，業務の質を高めるための手段として電 算機を利用することは非常に有用である.

病院薬剤部の電算化については，医療情報システム化 の一分野としての面からとらえたり，1) 日本病院薬用 師 会学術委員会第 5 小委員会(「病院薬局における電算機の 利用」)で検討されており，2）また各病院においてもさま ざまな角度からのアプローチがなされている.フメリカ における病院薬局の電算化の現状についての報告》西 る.

そこで病院薬㶡部の電算化の現状を把握するために， 全国国立大学病院および電算機利用が進められている病、 院についてアンケート調查を行った. 


\section{解 查方 法}

\section{1. 的亘対象}

国立大学病院 40 , 私立大学病院 2 , 一般病院 12 , 合計 54病院を調査対象病院としてアンヶートを送付した。な お私立大学病院および一般病院についてはすでに電算機 を導入し，電算化の進行している病院であり，国立大学 病院の電算化状況と比較するために調査を行ったもので ある.

\section{2. 調查内容}

(1) 病院における電算化

(1)電算機導入状況，機種，内部記憶容量，(2)電算化業 務と稼動状況，(3)入力方式

(2)薬凧部における電算化

(1)病院電算機との接続状況，接続機器，台数，設置 室, (2)薬剤部のみの電算機導入状況, 機種, 内部記憶容 量, 設置室, (3)電算化業務と稼動状況, 使用機種

(3)医薬品コード

(4)薬品管理業務の電算化

(1)システム, (2)出力帳票, リスト, (3)出力帳票を法定 帳簿としての使用の有無, 使用の根拠, (4)自動発注方式 と対象品目

(5)調剂，薬品情報，その他の業務の電算化
(1)システム，(2)出カリスト

(6)電算化と薬剂部の対応

(1)開発担当者ならびに専任，兼任の区分，(2)初期教育 方法, (3)部内開発チームの有無

(7)ソフトウェアの共同利用

(1)共同利用の意思，(2)利用可能なシステム，媒体

(8)薬剤部業務の電算化に対する意見

(9)薬凮部業務の電算化システムの概要 ·

(1)名称, (2)稼動状況，(3)説明，特徵，(4)概要図，(5)開 発年度, 開発期間, (6)設計担当者, (7)プログラム開発担 当者, (8)記述言語, (9)メンテナンス担当者, (10)運用担当 者, (11)首入のメリット,デメリット.デメリットへの対 応, 12対象医薬品数

以上のような項目について調查した。な执電算化状況 に関する質問は，システムが稼動中あるいは計画中の病 院に対して行った.

\section{調查結 果}

国立大学病院（40）（以下，国立とする）, 電算化の進 行した私立大学病院 (2) および一般病院 (13) (以下, その他とする）より回答があり，回収率は $98.1 \%$ である （表 1 ).

表 1 . 協 力 病 院 名

\begin{tabular}{|c|c|c|c|}
\hline \multicolumn{4}{|l|}{ 1. 国立大学病院（40病院） } \\
\hline 北海道大学病院 & 九昍川医科大学病院 & 弘前大学病院 & 東北大学病院 \\
\hline 秋田大学病院 & 山形大学病院 & 筑波大学病院 & 群馬大学病院 \\
\hline 千集大学病院 & 東京大学病院 & 東京大学分院 & 東京医科歯科大学病院 \\
\hline 新渴大学病院 & 富山医科薬科大学病院 & 金沢大学病院 & 信州大学病院 \\
\hline 岐点大学病院 & 浜松医科大学病院 & 名古屋大学病院 & 三重大学病院 \\
\hline 滋嘪医科大学病院 & 京都大学病院 & 大阪大学病院 & 神戸大学病院 \\
\hline 鳥取大学病院 & 身根医科大学病院 & 岡山大学病院 & 広島大学病院 \\
\hline 山口大学病院 & 徳島大学病院 & 高知医科大学病院 & 愛媛大学病院 \\
\hline 九州大学病院 & 佐贺医科大学病院 & 長崎大学病院 & 熊本大学病院 \\
\hline 大分医科大学病院 & 宮崎医科大学病院 & 鹿児島大学病院 & 琉球大学病院 \\
\hline \multicolumn{4}{|l|}{ 2. 私立大学病院 (2病院 ) } \\
\hline 北里大学病院 & 東海大学病院 & & \\
\hline \multicolumn{4}{|l|}{ 3. 一般病院（11病院） } \\
\hline $\begin{array}{l}\text { 東京瓝传病院 } \\
\text { 東京都立広尾病院 } \\
\text { 神戸市立中央市民病院 }\end{array}$ & $\begin{array}{l}\text { 䦨東遁信病院 } \\
\text { 国立循環器病センター } \\
\text { 旡数中央病院 }\end{array}$ & $\begin{array}{l}\text { 東京都立駒込病院 } \\
\text { 東大阪市立中央病院 } \\
\text { 東洋工業湖東洋病院 }\end{array}$ & $\begin{array}{l}\text { 日赤医療センター } \\
\text { 西宮市中央病院 }\end{array}$ \\
\hline
\end{tabular}

\section{1. 病院におけるの西化}

各病院における電算機の尊入状況は国立大学病院の $62.5 \%$ が導入， $35.0 \%$ が計画中である．情報処理を一つ の大型計算機で行ら集中システムにするか，あるいはい くつかの小型計算機で処理する分散システムにするか
は, 病院の性格, 規模, 電算化に対する取り組み方によ り異なるが，各病院導入の電算機機種によると前者の集 中システムを志向する病院が多いようである(表 2).

電算機を導入（計画中も含む）している病院の電算化 システムには患者登録（国立 $59.0 \%$ ，その他 $92.3 \%$ ), 
医事会計（国立 $56.4 \%$ ，その他 $92.3 \%$ )，病歷管理（国 立 $25.6 \%$ ，その他 $53.8 \%$ ），物品管理（国立 $15.4 \%$ ，そ の他 $23.1 \%$ ）などが稼動しており，事務処理や管理業務 の効率化に大きなメリットを期待する病院が多い．また

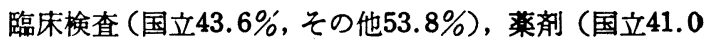
$\%$ ，その他 $84.6 \%$ )，放射線（国立 $12.8 \%$ ，その他 23.1 \%) など病院内各部門での電算化が進行している（表 3).

表 2. 病院電算機の種類（上位10機種）

\begin{tabular}{|c|cc|cl|}
\hline 機 & \multicolumn{2}{|c|}{ 名立大学病院 ( 39病院) } & その他の病院 (13病院) \\
\hline FACOM M-15OF & 6 & $15.4(\%)$ & 1 & $7.7(\%)$ \\
NEC ACOS 350 & 4 & 10.3 & 0 & 0 \\
NEC ACOS 450 & 3 & 7.7 & 1 & 7.7 \\
FACOM M-130F & 3 & 7.7 & 1 & 7.7 \\
FACOM M-16OF & 3 & 7.7 & 0 & 0 \\
IBM 4341 & 2 & 5.1 & 1 & 7.7 \\
NEC ACOS 250 & 1 & 2.6 & 2 & 15.4 \\
FACOM M-17OF & 2 & 5.1 & 0 & 0 \\
DEC PDP11/70 & 2 & 5.1 & 0 & 0 \\
DEC PDP11/34 & 2 & 5.1 & 0 & 0 \\
\hline
\end{tabular}

表 3. 病院における電算化システム

\begin{tabular}{|c|c|c|c|c|}
\hline & 国立大学病 & (39病院 ) & その他の病 & (13病院) \\
\hline & 穆動中 & 竍面中 & 稼 & 竍面中 \\
\hline 者 登 録 & $23 \quad 59.0 \%$ & $820.5 \%$ & $12923 \%$ & $0 \%$ \\
\hline 医事会 幛 & 2256.4 & $7 / 7.9$ & 12923 & 0 \\
\hline 臨 床 検 查 & $17 \quad 43.6$ & 923.1 & 753.8 & 7.7 \\
\hline 葅 & $16 \quad 41.0$ & $7 / 7.9$ & 1184.6 & 0 \\
\hline 病 歴 管 & 1025.6 & $10 \quad 25.6$ & 753.8 & 0 \\
\hline 給＼cjkstart食 & 923.1 & $13 \quad 33.3$ & 5385 & 0 \\
\hline 物品管理(事務部) & $6 \quad 15.4$ & 37.7 & 323.1 & $\begin{array}{ll}3 & 23.1\end{array}$ \\
\hline 放 射 線 & $5 \quad 128$ & $5 \quad 128$ & $3 \quad 23.1$ & 17.7 \\
\hline 護 & 37.7 & 25.1 & 17.7 & 7.7 \\
\hline 手 術（栖） & 25.1 & $5 \quad 128$ & 7.7 & 0 \\
\hline 集中治療 (救急) & 5.1 & & 215.4 & 7.7 \\
\hline 冠動脤疾患治洣 & 5.1 & 2.6 & 00 & 0 \\
\hline 医療器 材 & 5.1 & $4 \quad 10.3$ & 17.7 & 7.7 \\
\hline 臨床デー夕処理 & 5.1 & $3 \quad 7.7$ & 5385 & 7.7 \\
\hline 輸 血 & 2.6 & 7.7 & 00 & 0 \\
\hline 他 & 0 & 2.6 & 430.8 & 0 \\
\hline
\end{tabular}

\section{2. 入カ丶式}

医療および薬物療法の質的向上をはかるために電算機 に蓄積したデータを参照することは有用である。そのた めには入力データの信頼性は高い水準にあることが要求 される. 各病院の入力方式は集中入力（国立 $35.9 \%$ ，そ の他 $7.7 \%$ )，分散入力 (国立 $23.1 \%$ ，之の他 $53.8 \%$ ), 発生源入力（国立7.7\%，その他 $23.1 \%$ )，集中入力之発 生源入力の組合せ（国立 $12.9 \%$ ，その他 $15.4 \%$ ）である (表 4).
病院での診療行為データの有効利用を考虑すると, 最 適な入力方式は医師による発生源入力であり, 今後この 方式を志向したシステム開発が望まれる. 東京都立駒込 病院や高知医科大学病院では電算機出力の処方せんによ る調剂業務を行っている.4,5) これは発生源入力を前提と したシステムで初めて可能である.

その他の入力方式の場合は入力によるミス等種々の条 件により医療事故につながる危険性を考え，電算機出力 の処方せんをそのまま調剤に利用することは避けるべき 
表 4. データの入力方式

\begin{tabular}{|l|rc|cc|}
\hline & 国立大学病院 (39病院) & その他の病院 (13病院) \\
\hline 発生源入力 & 3 & $7.7 .(\%)$ & 3 & $23.1(\%)$ \\
菜中入力 & 14 & 35.9 & 1 & 7.7 \\
分散入力 & 9 & 23.1 & 7 & 53.8 \\
組合せ入力 & 5 & 12.9 & 2 & 15.4 \\
\hline
\end{tabular}

である。

\section{3. 䓠玮部における而化}

薬剤部業務は薬務, 薬品在庫管理, 麻薬管理などの事 務処理を主としたものと, 調剤, 製剂, 桼品情報, 試験 - 研究業務などに大別される. 最近は処方せん枚数, 採 用薬品数の増加が著しく, それに伴って取扱う情報量も 増大している.また薬物血中濃度測定等の臨床薬学的研 究などの新しい分野の業務も重要性を增している. しか しながら薬剤部職員の限定した人数をもって患者および 院内各部門へのサービス向上ならびに薬凧部業務の質的 向上をはかることは困難な状況になってきている.

それを克服するためには電算化に対する薬剤部職員の 一致した努力による効率的なシステムの運用が必要であ る.なお電算化に際しては多くの予算, 開発期間, 労力 を必要とするため, 薬鄅部業務を十分に分析した上でシ
ステム設計にとりかかり，同時にシステム稼動後のメリ ット, デメリットについてもあらかじめ配虑しておく必 要がある. 薬剤部業務は院内各部門の業務と深く関連し ており，電算化に際しては単に薬剤部としてのみではな く, 病院全体としての機能を向上させるようなシステム 化をはかる必要がある.

病院導入の電算機と薬剤部とを接続している病院（国 立53.8\%, その他76.9\%) は薬品管理室, 調剂室, 薬品 情報室などに端末装置を設置している（表 5 ）. また, 病 院内設置の電算機とは別に薬剤部独自でオフュン, マイ コンなどの導入も行っている（表 6 ).

電算化対象業務の中で最も多いのは薬品管理（国立 47.5\%，その他 $84.6 \%$ ) である.この他調剂（国立 22.5 $\%$, その他 $38.5 \%$ ), 薬品情報（国立 $12.5 \%$, その他 $30.8 \%$ ) や薬物血中濃度測定（国立 $17.5 \%$ ）などのシス

表 5. 病院電算機と桼剤部の接続状況

\begin{tabular}{|c|c|c|c|c|}
\hline & \multicolumn{2}{|c|}{ 国立大学病院（39病院） } & \multicolumn{2}{|c|}{ その他の病院（13病院） } \\
\hline & 端末末装 且 & 印刷装置 & 端末末装置 & 印刷装置 \\
\hline $\begin{array}{r}\text { 菓品䇫理 } \\
2 \text { 台 } \\
1 \text { 台 }\end{array}$ & $\begin{array}{c}153^{385 \%} \\
12\end{array}$ & 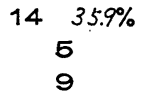 & 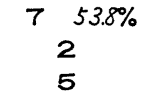 & 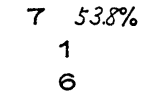 \\
\hline $\begin{array}{r}\text { 剂 } \\
2 \text { 台 } \\
1 \text { 台 }\end{array}$ & $\begin{array}{c}25.6 \% \\
1 \\
9\end{array}$ & $\begin{array}{c}9 \\
2 \\
7\end{array}$ & $\begin{array}{c}323 . / \% \\
0 \\
3\end{array}$ & $\begin{array}{l}3 \\
2 \\
1\end{array}$ \\
\hline $\begin{array}{r}\text { 薬品情報 } \\
2 \text { 台 } \\
1 \text { 台 }\end{array}$ & $\begin{array}{l}7 \\
2 \\
5\end{array}$ & $0_{0}^{0 \%}$ & $10^{17.7 \%}$ & $0_{1}^{17 \%}$ \\
\hline $\begin{array}{r}\text { の 他 } \\
2 \text { 台 } \\
1 \text { 台 }\end{array}$ & $\begin{array}{l}0 \% \\
0 \\
0\end{array}$ & $0_{0}^{0 \%}$ & $\begin{array}{c}21_{1}^{15.4 \%} \\
1\end{array}$ & $\begin{array}{l}0 \% \\
0 \\
0\end{array}$ \\
\hline
\end{tabular}

表 6. 薬剈部独自の電算機

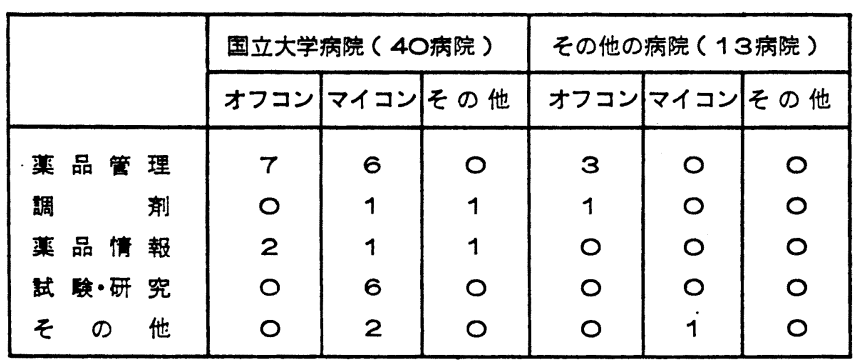


表 7. 薬剤部業務の電算化

\begin{tabular}{|c|c|c|c|c|}
\hline & \multicolumn{2}{|c|}{ 国立大学病院 ( 40病院 ) } & \multicolumn{2}{|c|}{ その他の病院 (13病院) } \\
\hline & 稼動中 & 幛画中 & 稼勤中 & 竍画中 \\
\hline 薬 品 管 & $1947.5 \%$ & $11 \quad 27.5 \%$ & $11 \quad 84.6 \%$ & $0 \%$ \\
\hline 調 & 922.5 & 25.0 & 538.5 & 430.8 \\
\hline 蒋 品 情 & $5 \quad 12.5$ & 1127.5 & 430.8 & 430.8 \\
\hline 威 & 12.5 & 37.5 & 00 & 323.1 \\
\hline 注射薬交付 & 410.0 & 615.0 & 215.4 & 323.1 \\
\hline 晽 薬 管 理 & 00 & 5.0 & 7.7 & 7.7 \\
\hline 薬 歴 調 & 2.5 & $5 \quad 12.5$ & 15.4 & 15.4 \\
\hline 薬物血中榩度測定 & $7 / 7.5$ & 615.0 & 00 & 430.8 \\
\hline そ の 他 & 410.0 & 37.5 & 215.4 & 0 \\
\hline
\end{tabular}

\section{テムが稼動している（表 7).}

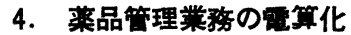

薬品管理業務の一般的な運用は薬務空あるいは薬品管 理室を中心として, 各診療科外来・病棟, 事務部, 業 者, また調剤室, 製剂室などの薬剤部内各部署間で伝票 と薬品をやりとりし, 薬品購入計画, 消費管理, 請求・ 払出管理，在庫確認などを行ら（図 1)。これらの業務を 円滑に遂行するため, 西るいは帳票, リスト作成のため
電算化は有効である．薬品管理業務の電算化は事務処理 の繁雑さを軽減し，また一般の在庫管理と共通する部分 もあり, 病院薬剤部でも比較的早い時期から電算化を進 めている.対象業務として薬品入庫(国立 $40.0 \%$ ，その他 $92.3 \%$ ), 薬品出庫(国立 $37.5 \%$, その他 $92.3 \%$ ), 自動発 注（国立 $17.5 \%$ ，その他 $61.5 \%$ ）などがあり，そのデー 夕を利用して帳票作成（国立 $35.0 \%$ ，その他 $84.6 \%$ ) や 統計資料作成（国立 $17.5 \%$ ，その他 $92.3 \%$ ）が行われて

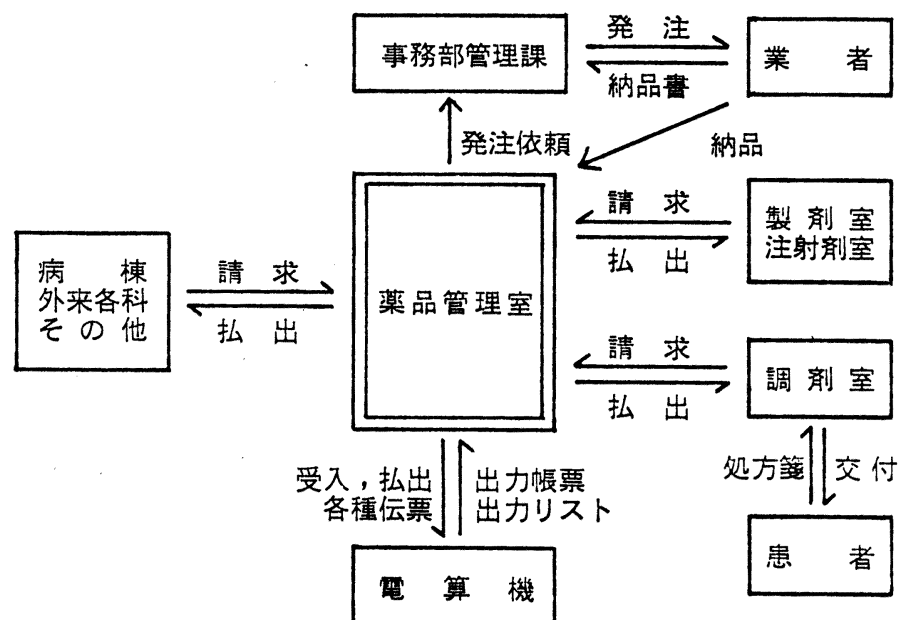

図 1. 薬品管理業務

表 8. 薬品管理業務の電算化

\begin{tabular}{|c|c|c|c|c|}
\hline & \multicolumn{2}{|c|}{ 国立大学病院 (40病院 ) } & \multicolumn{2}{|c|}{ その他の病院 (13病院) } \\
\hline & 稼動中 & 尌画中 & 稼動中 & 計画中 \\
\hline 桼品入庫 & $1640.0 \%$ & $615.0 \%$ & $1292.3 \%$ & $0 \quad 0 \%$ \\
\hline 薬品出庫 & 1537.5 & 615.0 & 1292.3 & 00 \\
\hline 自動発注 & $7 / 7.5$ & 25.0 & $86 / .5$ & 00 \\
\hline 帳票作成 & 1435.0 & 615.0 & 1184.6 & 0 \\
\hline 統尌盗料 & $7 / 7.5$ & $7 \quad 17.5$ & 1292.3 & 0 \\
\hline その他 & 25.0 & $1 \quad 2.5$ & 323.1 & 0 \\
\hline
\end{tabular}


いる (表 8).

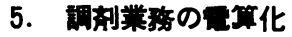

調剂業務に関連する電算化は薬袋 (ラベル) (国立10.0 $\%$ ，その他 $15.4 \%$ )，統計資料作成（国立 $7.5 \%$ ，その 他 30.8\%) などである（表 9). 九州大学病院では医事 会計システムに打ける患者情報や点数マスターファイル
中の薬風情報と処方せんの入力情報を参照して漢字印刷 装置で自動作成した薬袋を利用した入院定期調剤システ $\Delta^{6)}$ が稼動している．このシステムは薬袋書記時間の短 縮, 処方せんチェックの徹底, 調剤の画一化, 外来患者 待時間の短縮などを目的としたものである.

表 9. 調刘業務の電算化

\begin{tabular}{|c|c|c|c|c|}
\hline & \multicolumn{2}{|c|}{ 国立大学病院 (40病院 ) } & \multicolumn{2}{|c|}{ その他の病院 (13病院 ) } \\
\hline & 楾動 中 & 郭画中 & 稼動 中 & 計画中 \\
\hline 薬袋 (ラペル) & $4 \quad 10.0 \%$ & $12.5 \%$ & $2.15 .4 \%$ & $0 \quad 0 \%$ \\
\hline 監＼cjkstart查 & 12.5 & 00 & 00 & 00 \\
\hline 統尌 资 料 & 37.5 & 00 & 430.8 & 7.7 \\
\hline その 他 & 12.5 & 00 & 215.4 & 0 \\
\hline
\end{tabular}

表 10. 薬品情報業務の電算化

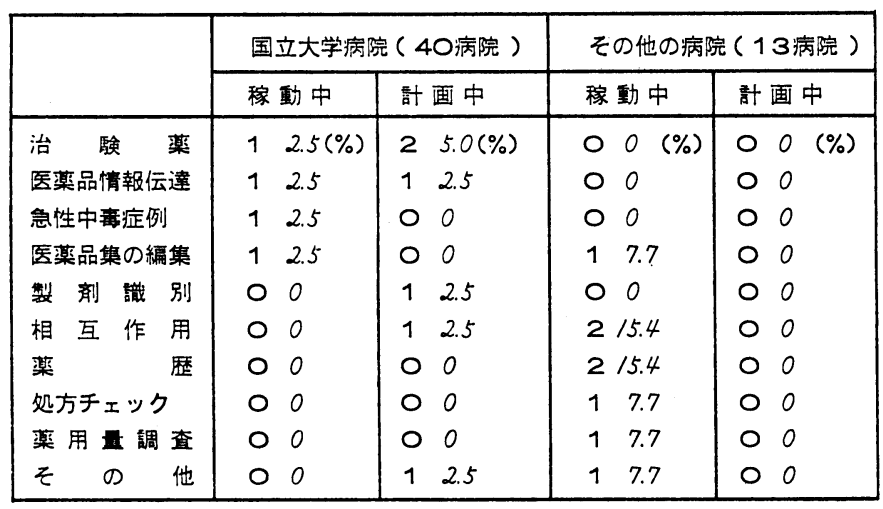

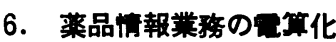

薬剂化関する情報は際限なく增加しており，情報の処 理は従来の手作業的な対応では応じきれなくなってい る. 常佂正確さ, 的確さ, 迅速性, 再現性や up-to-date の情報処理を必要とする薬品情報システムの電算化は妥 当なるのである.ところがシステムの開発からメンテナ ンスまでを一つの病院で行らことは非常に困難であり， 現在は少数の病院でしか稼動していない状況である（表 10).

京都大学病院の医薬品情報伝達システム ${ }^{7,8)}$ や東京大 学病院の治験薬情報検索システム ${ }^{9,10)}$ はオンライン検索 以外に磁気テープのコピーの提供を行いデータベースが 広く利用可能である. しかしデータの維持・管理には常 飞注意を払っておかかねばならず，多くの時間，労力を必 要とする. したがって，いくつかの病院が協力してデー タベースを作成し維持する，いわゆるシステムの共同開 発, 共同利用構想の推進が望まれる.

\section{7. 医莱品コート}

情報処理上，医薬品コードの設定は重要である．現状 では各病院で随意に設定しているが，桁数は $4 \sim 7$, 使 用文字は数字のみ, あるいは英字, 数字, カナ文字の組 合せが多いようである (表11).

コードを設定するにあたり，使用目的，使用範用が不 明確なまま設定すると電算化の過程で不都合な問題が生 じる打それがあり，桁数，形態等の採用には十分留意す る必要がある。

各病院使用コードとは別に全国的に統一したコードを 作成し, 情報システム相互利用役役立てることが望まし いが，現状では統一コードの実現は困難である．したが って厚生省が作成した薬価基準収載医薬品コード11) 亿基 つくくコードや医療情報システム開発センター（MEDISDC)，日本医薬情報センター（JAPIC）で開発中の医薬 品情報データベース’2のコードの使用がよいものと考兄 る. 
表 11. 医薬品コード

\begin{tabular}{|c|c|c|c|c|}
\hline & \multicolumn{2}{|c|}{ 国立大学病院 ( 40病院 ) } & \multicolumn{2}{|c|}{ その他の病院 (13病院 ) } \\
\hline 枌 & 1 & $2.5(\%)$ & 1 & $7.7(\%)$ \\
\hline 标 & 4 & 10.0 & 1 & 7.7 \\
\hline 桁 & 12 & 30.0 & 5 & 38.5 \\
\hline 枌 & 6 & 15.0 & 3 & 23.1 \\
\hline 标 & 3 & 7.5 & 2 & 15.4 \\
\hline 桁 & 0 & 0 & 1 & 7.7 \\
\hline そ の 他 & 4 & 10.0 & 0 & 0 \\
\hline 数 字 の み & 15 & $37.5(\%)$ & 10 & $76.9(\%)$ \\
\hline 英, 数, カナ文字 & 7 & 17.5 & 1 & 7.7 \\
\hline 数字, カナ文字 & 4 & 10.0 & 1 & 7.7 \\
\hline 英字，数 字 & 3 & 7.5 & 1 & 7.7 \\
\hline 英字, カナ文字 & 1 & 2.5 & 0 & 0 \\
\hline
\end{tabular}

表 12. 薬剤部システムの開発担当

\begin{tabular}{|c|c|c|c|c|}
\hline & \multicolumn{2}{|c|}{ 国立大学病院 ( 40病院) } & \multicolumn{2}{|c|}{ その他の病院 ( 13 病院 ) } \\
\hline 蒋剂部職員 & & $45.0(\%)$ & 6 & $46.2(\%)$ \\
\hline 院 内機 閶 & 4 & 10.0 & 6 & 46.2 \\
\hline メ - カ - & 5 & 12.5 & 2 & 15.4 \\
\hline そ の 他 & 3 & 7.5 & 3 & 23.1 \\
\hline
\end{tabular}

表 13. 薬剤部職員の開発担当

\begin{tabular}{|l|cc|cc|}
\hline & 国立大学病院 (40病院) & その他の病院 (13病院) \\
\hline 豆任のみ & 0 & 0 (\%) & 0 & 0 (\%) \\
兼任のみ & 15 & 37.5 & 4 & 30.8 \\
䙳任+兼任 & 3 & 7.5 & 1 & 7.7 \\
不 明 & 0 & 0 & 1 & 7.7 \\
\hline
\end{tabular}

表 14. 初期教育の方法

\begin{tabular}{|l|cc|cl|}
\hline & 国立大学病院 (40病院) & その他の病院 (13病院) \\
\hline 独 習 & 7 & $17.5(\%)$ & 1 & $7.7(\%)$ \\
学内機 & 4 & 10.0 & 1 & 7.7 \\
×ーカ- & 5 & 12.5 & 0 & 0 \\
その 他 & 1 & 2.5 & 1 & 7.7 \\
\hline
\end{tabular}

\section{8. 薬剂部システムの四発坦当者}

薬凮部システムの開発は薬剤部職員（国立 $45.0 \%$, そ の他 $46.2 \%$ ), 院内機関（国立 $10.0 \%$, その他 $46.2 \%$ ), メーカー（国立12.5\%，その他 $15.4 \%$ ）などが担当して いる(表12). 薬剤部職員の開発担当は兼任のみ(国立37.5
\%, その他 30.8\%), 専任と兼任（国立 7.5\%, その他 $7.7 \%$ )であり, 専任のみとしている病院はない（表13). 開発担当者の初期教育方法は独習（国立 $17.5 \%$, その 他 $7.7 \%$ ), 学内機関の教育(国立 $10.0 \%$, その他 $7.7 \%$ ), メーカーの講習（国立 12.5\%) などである（表 14）. 
電算化に際して薬剈部職員の関与はよりよいシステム を設計する上で重要である．現状では薬剩部の人員増を 期待することは困難であり，薬珴部業務の再検討を行 い, 開発担当のための人員を捻出する必要がある.

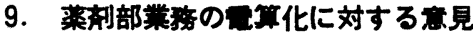

病院の電算化に伴い薬刜部業務の電算化は払大する方 向にある. 薬品在庫管理など事務処理のみでなく, 調 剂, 薬品情報, 薬物血中濃度測定などに応用するなど利 用分野は幅広いものである．同時に電算化によって医療 の質的向上に寄与するシステムづくりが重要である．シ ステムの開発にあたっては病院内の関係部署と密接な関 連を保ち, 病院トータルシステム構想を考虑し, その際 には発生源入力方式が望ましい，薬鄅業務の電算化，特 に薬品情報のシステム化は一病院だけでは困難であり, 共同開発, 共同利用の方向性が望ましい，共同利用の推 進に重要と考えられる医薬品コードの統一化をはかる必 要がある。

\section{まとめ}

薬剤部業務の著しい增加, 質的向上に対処するため, システムの効率よい電算化は必須である. 現在, 事務処 理の合理化を目的とした薬品在庫管理や料金計算などの 電算化の方法はすでに確立しているものと考える。しか しながら医療の中で大きな役割を占める薬剤に関する情 報を薬物療法の合理化, 改善, 安全性確保などに利用す るシステムについては未だ十分でなく，むしろこれから の課題である.

MEDIS-DC や JAPIC で開発中の医薬品情報データ ベースは添付文書の内容を基本として作成しており，各 病院に拈いてこのデータベースの有効な利用方法を考兄 るとともに, 個々の病院で必要とするデータを追加して いけば，より充実した薬品情報のシステム化がはかられ ると考える．また薬剤識別用データベース,1(1) 注射剂混 合に関するデータべース, 13) 知識工学の手法を用いた処

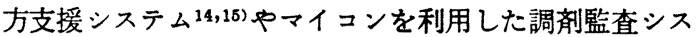
テム16-18)の開発るなされている.

入力情報による薬歴と患者情報や薬剤情報とを参照し た配合禁忌, 相互作用, 禁忌症, 長期連用時の副作用な どのチェックを行らことは，今後薬剤部における電算機 利用の中でも重要な部分を占め，適正な薬物療法をはか る上で有用である．このような方向性をシステムに反映 するため, 薬阂部は情報処理専門家を中心とする病院シ
ステム開発チームに積極的に参加し, また薬剤部内でる 十分なディスカッションを重ねる必要がある.

期辞 この調查は，第16回全国国立大学医学部附属病 院薬剤部実務担当官会議の資料として作成したものであ り，で協力をいただいた各病院に深謝する。

\section{文㰴}

1）開原成允, 稲田紿: 医療情報学, 情報処理 学 会 1980 .

2）田村善蔵，青山敏信，石出明敏，北澤式文，相良 悦郎, 笹井節三, 朝長文弥, 中島新一郎, 中村幸 一: 病院薬学, 7, 76 (1981)；8，34 (1982).

3) K.W.Burleson : American Journal of Hospital Pharmacy, 39, 53 (1982).

4) 伊藤一二, 小出保爾, 斎藤忠雄 : 最新医学, 34 , 2668 (1980).

5）相良悦郎，西岡豊，国沢昌弘，小倉久和，北添康 弘, 武田佳彦: 薬剤学, 42, 246 (1982).

6）米澤和明，中尾泰史，園田正信，野仲範子，唐沢 博順, 青山敏信, 堀岡正義: 病院薬学 (投稿中).

7）北澤式文：ファルマシア，17,963 (1981).

8）北澤式文：第 1 回医学・生物学に関する情報学連 合大会論文集, 291 (1981).

9）中村幸一，浜田潤，佐山節子，斎藤侑也，田村善 蔵, 川村昇, 開原成允: 病院楽学, 7,118 (1981).

10）土屋文人, 中村幸一, 倉本加代, 浜田潤, 原田知 于, 清水秀行, 新述順子, 斎藤侑也, 川村界, 開 原成允：第 1 回医学・生物学に関する情報学連合 大会論文集, 341 (1981).

11）医薬情報研究所: 薬価基準収載医楽品コード表 1981 .

12）医療情報システム開発センター：医療情報システ 厶研究開発報告蕃概要, 23 (1982).

13）近藤順子，中村幸一，浜田潤，土屋文人，原田知 子, 福田智子, 斎藤侑也, 川村昇, 大久保昭行, 開原成允：第 2 回医療情報学連合大会論文集, 87 (1982).

14）開原成允，川村昇：日本臨床，39，春季増刊号， 844 (1981)

15）土屋文人，原田知子，木村通男，小山照夫，八日 市谷隆, 開原成允, 清水喜八郎：第 2 回医療情報 学連合大会論文集, 91 (1982)。

16）中尾泰史, 青山敏信, 堀岡正義, 家串稔, 村上克 幸：日本薬学会第102年会講演要旨集, 678(1982).

17）家电稳, 守口淑秀, 池内嘉郎, 村上克幸, 中尾泰 史, 野仲籍子, 小坪一哉, 高橋雅治, 青山敏信, 堀岡正義：日本薬学会第102年会講演要旨集, 678 (1982).

18）小西豊次, 松岡芳文: 月刊薬事, 24,2103 (1982). 